\title{
The Alash Party: Historiography of the Movement
}

Z.G. Saktaganova, ${ }^{+*}$ B.K. Omarova, ${ }^{\prime}$ K.M. Ilyassova, ${ }^{*}$ Z.N. Nurligenova, ${ }^{\top}$ B.Zh. Abzhapparova, ${ }^{\ddagger}$ A.Zh. Zhalmurzina, '́ and Zh.S. Mazhitova ${ }^{\prime}$

\section{Abstract}

This research presents a short historiographical review of the Alash movement. It reflects the researchers' own version of periodisation of the history of the first Kazakh national party Alash that belonged to the liberal democratic wing. The researchers identify four stages in the history of the movement connected with the main landmarks of its short, yet significant existence. The periods of Alash history are determined based on changes in strategy and tactics, as well as the evolution of its organisational forms (a movement - a party during elections to the Constituent Assembly - the ruling party in the Alash Autonomy and Alash Orda government). A conclusion is made that national parties set forth the conditions and ways of modernisation in the most acceptable forms and combinations for each corresponding nation; possible parallels in the development pathways followed by other national parties in 1918-1920 are pointed out.

Keywords: History of Kazakhstan in the 20th Century; Soviet History; Political Parties of Kazakhstan; Alash; Alash Orda; Stages in the History of the Alash Party

\footnotetext{
${ }^{\dagger}$ Karaganda State University named after E.A. Buketov, Universitetskaya Street, 28, Karaganda, 100028, Kazakhstan

*Corresponding Author, Email: z_saktaganova@inbox.ru

Í JSC “Astana Medical University”, Beibitshilik Street, 49A, Astana, 010000, Kazakhstan

$¥$ L. N. Gumilyov Eurasian National University, Satpayev Street, 2, Astana, 010000, Kazakhstan

' Karaganda State Technical University, Mira Boulevard, 56, Astana, 100028, Kazakhstan

(C) 2020 Saktaganova et al. This is an Open Access article distributed under the terms of the Creative Commons Attribution License (http://creativecommons.org/licenses/by/2.0), which permits unrestricted use, distribution, and reproduction in any medium, provided the original work is properly cited.
} 


\section{Introduction}

The Alash party was the first national party in the history of Kazakhstan that committed itself to the restoration of national statehood. A whole series of scientific and publicistic works devoted to the history of the Alash movement and the Alash party has emerged in the modern Kazakh and Russian historiography. However, studies of the history of this party started a century ago, as early as in the middle of the 1920s, when the Bolsheviks declared it bourgeois-nationalistic, so the main purpose of such publications was dispelling of the "counter-revolutionary Alash Orda" (Bochagov, 1927; Kenzhin, 1922; Ryskulov, 1984). Notwithstanding the preceding, these publications contained valuable materials - documentary evidence of activities conducted by Alash. Therefore, it is no coincidence that these works were subsequently forbidden, and their authors were subjected to repression (Martynenko, 1992; Brainin, 1933; 1935). Yet very soon, starting from the middle of the 1930s, when the newspaper Pravda published a devastating article on Alash Orda and social discussion about the same started taking place; talking of the history of the Alash movement became highly dangerous, even from the perspective of criticism, and historians left this topic out of their research field for a long time. During the Soviet period, no research was carried out on the Alash party until the end of the 1980s - beginning of the 1990s. It was mentioned in the general context within the studies of the October Revolution of 1917; the establishment of the Soviet rule in Kazakhstan and the Civil War; but orthodox Bolshevist interpretations of the party's activities were retained in these publications (Grigoryev, 1989; Sarmurzin, 1990; Mazhitova et al., 2016). Only when the Republic of Kazakhstan gained independence, first works by Kazakh researchers, such as M.K. Koigeldiev, K.N. Nurpeisov, M.K. Kozybaev, S. Akkuly, etc. appeared, providing for an unbiased evaluation of the role Alash had played in the Kazakh national movement. In the 1990s - 2000s, several monographs by the Russian historian-
D.A. Amanzholova were published, which examined the history of the Alash movement from new conceptual perspectives in a comprehensive way. Besides, a substantial number of new materials from Russian archives that had not been used before were published at the same time (Akkuly, 2016; Amanzholova, 1993; 1994). Works by D.A. Amanzholova are marked by an analytical and systemic approach to the issue of the Alash movement. The body of literature released over the 1990s - 2000s grew so large that the first monograph devoted to the historiography of this topic came out (Nurmagambetova, 2003).

The research is organised as follows: it started with an introduction section, which demonstrated the need to study the history of the Alash party by presenting a brief history of the party and its significance. There are quite a few studies of the Alash party completed over the past 30 years. The party has existed since the beginning of the 20th Century, but only in the last 30 years, scholars gained access to archival materials. The study used data from archives, researchers, as well as open sources. In results, the researchers identify the main periods in the development of this party. The results of the study can be used for a comparative analysis of the development of national parties in the early 20th Century in Central Asia and the North Caucasus. The next section discusses the materials and methods deployed for this study.

\section{Materials and Methods}

The principle of historicism was used as the methodological basis of the research, which allowed us to examine the subject of the research in its dynamics. This principle of historicism further served as the lens of interrelation between the main social factors and conditions. The principle of scientific objectivity allowed us to analyse the subject matter taking into account social and political changes taking place in society. In the course of examination of the sources, we employed the systematic approach. Several variants of the periodisation of the Alash history were identified based on the analysis of various sources. Works 
written by Kazakh intellectuals in the first quarter of the 20th Century, periodicals and documents of the Alash party were used as primary sources underlying this study.

\section{Results and Discussion}

In this article, we would like to dwell upon the stages in the history of the Alash party. In the 1920s, the issues of periodisation of the Alash movement and stages in the history of the Alash party were discussed only in connection with discussions about the role of Kazakh intelligentsia. After the discussion about the role of Alash Orda organised by Kazakh Scientific Research Institute of Marxism-Leninism in 1935, a verdict was reached about the "counterrevolutionary nature" of Alash and Alash Orda. Soviet researchers never came back to the issue of Alash as a specific subject of research. Table 1 summarises the variants of periodisation suggested by Kazakh and Russian researchers.

Table 1: Variants of Periodisation of Alash History

Authors

T. Ryskulov

(Ryskulov, 1998: 268)

(Ryskulov, 1997: 236-237) (Ryskulov, 1997: 238)

\section{Variants of Periodisation}

\section{The 1920s}

Two stages in the history of the Alash party:

The 1st stage - before 1917 - the democratic stage: 1905-1913 - "the emergence of a pro-Western movement" "joining the Russian liberal political parties (the Constitutional Democratic party of Russia)";

19013-1916 - "the movement of Kazakh nationalistic intelligentsia is expanding and taking the shape of various interest groups organised nationwide, etc."

The 2nd stage - after February 1917 - the reactionary stage: the establishment of Alash political party;

From December 1917 - the period of "opposition of Alash Orda to the Soviet rule".

A. Bochagov (Bochagov, 1927: 210)

Before 1917 - the progressive revolutionary role of the party and its mass support among the population;

after 1917 - the counter-revolutionary period.

The 1990s-2000s

K. Nurpeisov (Koigeldiev, 1995: 125)

(Nurpesov, 1995: 122)

D.A. Amanzholova

(Amanzholova, 1994: 185186);

(Amanzholova, 2009: 349351)
1905-1907 - origins of the Alash movement and party;

1917-1920 - the establishment of the Alash party, the autonomy and its government and opposition to the Bolsheviks.

Three stages in the history of the Alash party:

1905-1916 - "a movement led by a liberal pro-Western group of intellectuals developed within the framework of the opposition movement of constitutional democratic and territorial communities";

1917 - from the organisation of Kazakh committees as national self-government authorities and regional congresses the movement proceeded to convene two nationwide forums and suggestion of new slogans - national-territorial autonomy within the Russian democratic federation and national party";

1918-1920 - the final stage on the history of the Alash party; antiBolshevik union with supporters of the democratic federation and the Constituent Assembly. 
In our opinion, the history of Alash movement could be connected to four stages carrying its key significant landmarks, which are identified as: 1905 - July 1917; July - December 1917; December 1917 - April 1918; April 1918 - March 1920.

The first Stage (1905 to July 1917): This is the period of the emergence of a pro-Western sociopolitical movement referred to as the Alash movement in modern literature. It is during this period when the political movement referred to in the corresponding studies as a pro-Western liberal democratic movement, which started spreading among the Kazakh national intelligentsia. Two substages can be identified within this period of development of the Alash movement: from 1905 to 1913 and from 1913 to July 1917 . During the first substage, the proWestern movement did not become dominating. However, with the launch of the newspaper "Kazakh" in 1913, the movement found its place in the socio-political arena, and the authority of the Alash movement gradually became the principal force in the Kazakh society.

A. Bukeikhanov states that initially "the general public was neutral about political issues...", but after the events of 1905, "the whole steppe got involved in the political sphere overwhelmed by the flow of liberation movement" (Bukeikhan, 1995: 75). New political trends and influences started penetrating the Kazakh society from large Russian cities. Characterising the political situation in Kazakhstan in 1910 in his work The Kirghiz, A. Bukeikhanov says that two main political movements were going to appear: a national religious movement (aiming for its ideal - religious unification of the Kirghiz with other Muslims; following the example of Muslim and Tatar parties) and a pro-Western movement (Party of People's Freedom serving as an example) (Bukeikhan, 1995: 77). However, considering the political situation before 1917 on the whole, we believe that it is possible to identify four political movements that penetrated the Kazakh steppe, filled a particular political space and found support in the society. As already stated, one of the political movements that spread among the Kazakh national intelligentsia is referred to as a proWestern liberal democratic movement. By this movement, A. Bukeikhanov means "intelligentsia brought up in the spirit of Russian literature, who believe in European culture, see the happiness of motherland in reasonable implementation of the achievements of Western culture and consider [that] religious issues [are] matters of secondary importance" (Bukeikhan, 1995: 76). According to A. Bukeikhanov, at the beginning of the 20th Century, pro-Western ideas did not become widespread in the Kazakh society because "as a result of Russifying policies prevailing in the Kirghiz steppe, it is still suspicious of Western education and culture" (Bukeikhan, 1995: 76). However, it is this Western influence that later became the focus of the most significant political events and processes. Consolidation of "pro-Western supporters" around A. Bukeikhanov, A. Baitursynov, M. Dulatov led to activisation of the pro-Western liberal democratic movement in the Kazakh society; the newspaper Kazakh became the mouthpiece of the intelligentsia, accumulating the most burning issues and shaping the public opinion of Kazakhs on these topics.

Another movement is traditionalist and panIslamic; in historiography, it is referred to as Muslim, or pan-Islamic. Characterising this movement, A. Bukeikhanov points out: "Intelligentsia, who were brought up in the oriental orthodox spirit and believed in its national and cultural exceptionalism, placed a premium on religion"; "...associating religious and national unity" (Bukeikhan, 1995: 76). Researchers emphasise that pan-Islamism penetrated the Kazakh steppe through Muslim clergy, Tatar and Central Asian, and became widespread in the south of Kazakhstan (Asfendiarov, 1993: 268).

Pan-Turkism was another separate movement in the Kazakh steppe. It should be mentioned that A. Bukeikhanov highlights that this movement was the most influential in the Kazakh environment: "in the most active circle of Kirghiz population, there was a majority of Turcophiles" (Bukeikhan, 1995: 76). S. Asfendiarov points out 
that pan-Turkism expressed the aspiration of the bourgeoisie of the most developed Turkic nations for the unification of the other; less developed Turkic peoples under their authority. The pan-Turkist and Dzhadidist movement were influential mainly in the western and northern regions of Kazakhstan (Asfendiarov, 1993: 269270).

The fourth movement was the social democratic movement. As we see it, it did not spread widely due to lack of social support: as a rule, it was represented by the urban democratic intelligentsia of different titles as well as proletarians.

Therefore, after 1913, when the newspaper Kazakh appeared, the pro-Western liberal democratic movement became the most influential in the steppe; started to gain ground and authority and expand its social support.

A. Bukeikhanov stresses orientation of proWestern supporters towards the Russian Constitutional Democratic party. Over this period A. Bukeikhanov, who was one of the leaders of pro-Western Kazakhs, joined the Constitutional Democratic Party and at some point became a member of its Central Committee. In 1905, Kazakh intelligentsia tried to establish a national subdivision of the Constitutional Democratic Party and thus encourage dissemination of liberal and democratic ideas in Kazakhstan. Later A. Bukeikhanov split with his fellow party members over a few strategic issues. Constitutional democrats dismissed the principle of the federative structure of Russia, standing up for the slogan of "cultural and national selfdetermination", which did not coincide with the hopes and wishes of Kazakh people and national intelligentsia. Leaders of Kazakh national intelligentsia advocated for the ideas of national and territorial autonomy and the slogan of "united indivisible Russia" suggested by constitutional democrats did not meet the hopes of Kazakh intelligentsia about autonomous Kazakhstan (Bukeikhan, 1995: 414). The events that took place in February 1917 pulled apart the two parties, constitutional democrats and Alash (seemingly, forever), but after October 1917 they found themselves on the same side - in the anti-Bolshevik coalition, and they were also both annihilated in Soviet Russia.

During this period, the national pro-Western intelligentsia led by A. Bukeikhanov showed political restraint, considering the open political struggle for the establishment of a national state untimely. Over this period their main goals were the following: development of a national language, literature and culture, protection of land from colonisation, and finally, protection of Islam (Bukeikhan, 1995: 75-76), which they perceived as a serious obstacle to the policy of compulsory Christianisation and Russification of the Kazakh population. After the first newspaper in the Kazakh language Dala ualayaty was closed, A. Bukeikhanov actively worked on the organisation of publication of newspapers in Kazakh and obtained permission to issue such a newspaper. Consequently, in February 1913, and as already mentioned above, the first issue of the Kazakh newspaper was published. The chief editor of the newspaper A. Baitursynov wrote in the first issue: "...[t]he problem of [the] existence of people is becoming acute. In order to preserve our autonomy, we have to fight with all our might for acquiring education and culture" (Proceedings of the Society for the Study of the Kyrgyz Krai, 1922: 21). Thus, the representatives of national intelligentsia focused their political, publicistic and educational activities on this area. They played a significant role in gradual cultural and political enlightenment of the general public, struggle against pan-Islamism, discussion and development of a common democratic platform for the national movement.

In 1917, all above-mentioned socio-political movements evolved and transformed into political parties. Based on pan-Islamic movement, in spring and summer of 1917 such parties as "Shura-i-Islamie", "Shura-i-Ulemiya" and "Dzhamilyat" emerged in southern regions of Kazakhstan and Central Asia. Pan-Turkism became a political platform for the Kirghiz socialist party "Ush-Zhuz" that appeared in the northern and northeastern regions of Kazakhstan in November 1917, which later 
became more left-wing and defected to the Soviet rule. The social-democratic movement transformed into several social democratic groups and organisations that were represented in 1917-1918 within the Russian Social Democratic Labour Party. As for the pro-Western liberal democratic movement, in 1917 the most influential party in the Kazakh steppe, The Separate Kirghiz (Kazakh) party was launched on its basis at the I All-Kazakh Congress and later was renamed as Alash.

So, this period was marked with the development of a new pro-Western sociopolitical movement referred to in the modern historiography as Alash. Having appeared in 1905 , it gradually expanded its social support, the active core of the movement was formed; the periodical press was established, and the movement became popular and gained authority in the Kazakh society. By encouraging consolidation of the Kazakh society, the Alash movement also promoted the growth of national consciousness, gained significant political and organisational experience. Various directions and forms of activity conducted by pro-Western national intelligentsia were developed over these decades: creation of national political press and active organisational and publicistic work in newspapers, journals, etc.; the petition movement; participation in organisation and calling political meetings and all-Kazakh congresses; involvement in the work of the I and II State Duma (the election campaign, agitation work and actual work as members of the Duma); activity in different government and social bodies (conventions of district officials, departmental meetings, activity of the NonRussian Affairs Department, etc.). After the fall of the monarchy in February 1917, political indifference and passivity of the Kazakh people in the sphere of politics gave way to the wish to take part in social and political changes, activisation of political processes, and awakening of national consciousness. The Kazakh society followed its leaders represented by the pro-Western liberal democratic intelligentsia in the course of these processes. D. Amanzholova reasonably notes that in order to understand the reasons for the popularity of the
Alash movement in the Kazakh society, it is necessary to take into account the influence of the firm traditionalist principles, charismatic nature of the movement leaders, and specific features of national movements in general, during the rise of which social-class priorities give way to national ones (Amanzholova, 2009: 153).

The second stage in the history of the Alash movement - (July - December 1917) - was an organisational period, when the first national political party appeared in Kazakhstan. After the monarchy was overthrown, the Kazakh national intelligentsia assumed that the democratic transformations that were being implemented in Russia would allow solving the problems of creation of a Kazakh national autonomy in a peaceful way and that cooperation with liberal democratic parties was possible. Intending to raise the question of the creation of a Kazakh national autonomy in the Constituent Assembly, A. Bukeikhanov and his followers actively supported democratic reforms implemented by the Provisional Government. Members of the Constituent Assembly could only be elected from political parties. By the summer of 1917, there had not been any national parties in the Kazakh steppe, and it was that election campaign that catalysed the process of creation of the first national liberal democratic party in Kazakhstan. In July 1917, at the I All-Kazakh Congress in Orenburg, the establishment of the Separate Kirghiz (Kazakh) party was announced. It got its name Alash later: on 5 July 1917 in the Kazakh newspaper (the official mouthpiece of the newly created party) published the following announcement: "We wish to call our party by the slogan of our ancestors - Alash."On 21 November 1917, a project of the party program containing ten points was published. The first section of the project of Alash program (written by A. Bukeikhanov, A. Baitursynov, M. Dulatov, E. Gumarov, E. Tormukhamedov, G. Zhundibaev, G. Birimzhanov) says that "Russia will be a democratic federal republic... Each state in the federal republic will be independent...". The second section says that "The regions inhabited by Kazakhs will join into a single whole, will have their own government and become one of the 
members of the Federation of the Russian Republic" (History of Kazakhstan, 2009). During this period, the Alash leaders supposed that Kazakh regions could join the Russian Federation as a national-territorial autonomy. According to D.A. Amanzholova, leaders of the Alash movement considered a federation to be the best form of legal regulation of the relationships between the centre and national and territorial entities. They believed that it provided a successful combination of the benefits offered by the state unity and centralised authority, on the one hand, and balanced independence of the federative members, on the other hand (Amanzholova, 1994: 31-32). Looking for independence in the form of autonomy without putting forward claims for full independence reflected the realistic position of Alash and relied on the objective state of the Kazakh society. The management of the Alash party took into account the deep integration of the region into the Russian political and economic systems, the historically developed interconnection between Russia and Kazakhstan, and the very high possibility of losing even minimal independence if sovereignty had been declared. The Alash movement sought to modernise the Kazakh society, speed up its progress relying on a reasonable combination of traditionalism with the best achievements of the Russian and European cultures and universal human civilisation.

Thus, at the second stage, the pro-Western socio-political movement transformed into a political party. It was the critical period of evolution, when the movement turned into a party - the stage of searching and development of a political platform in the new political environment marked with modernisation of the Russian society, elaboration of program strategies to be implemented by the young party, whereas there had been no such experience in this region, etc. However, this stage was very short, since the assumption of power by the Bolsheviks changed the situation. As a result of rejection to accept the Bolshevik policy, disapproval of their management methods, etc., the leaders of the Alash party had to reconsider the further way of development of the Kazakh society and statehood.

The third stage in the history of the Alash movement (December 1917 - April 1918) - the period of negotiations with Moscow about recognition of the Alash autonomy. The beginning of this period coincided with calling of an emergency II All-Kazakh Congress in December 1917, in the course of which the decision about establishment of the Alash autonomy was made, and the government of the autonomy of Kazakh regions called Alash Orda People's Council was elected. It was the period when Alash became the ruling party and conducted negotiations with the RSFSR government about recognition of the proclaimed Kazakh autonomy. The national intelligentsia received the Russian Revolution of 1917 extremely negatively. It is no coincidence that the resolution adopted at the II All-Kazakh Congress in December 1917 said that "at the end of October the Provisional Government was overthrown, the Russian Republic, which enjoyed credibility of the people and moral authority, lost its power, and, while any state authority is absent in the country, a civil war is possible..." (Martynenko, 1992: 68-69). Forecasts made by A. Bukeikhanov about the possible civil war, the danger "threatening the life and property of the Kazakh population" (Bukeikhanov, 1995: 75) caused by the new power came true very soon.

Although the Council of People's Commissars adopted the Declaration of the Rights of the Peoples of Russia on 2 November 1917, which proclaimed equality and sovereignty of peoples and their right to free self-determination up to secession and establishment of an independent state, this declaration did not convince $A$. Bukeikhanov of the sincerity of the Bolsheviks' intentions. On 1 December 1917, A. Bukeikhanov wrote "The Guide for Peasants, Workers and Soldiers", where he exposed the Bolshevik policy: "Ulyanov-Lenin, the Chairman of the Council of People's Commissars, rules the country single-handedly, just as Tsar Nicholas II, and does not want to report to anyone... Remember, peasants, workers and soldiers, that Bolsheviks consider: 1) accountability of the 
rulers to the people; 2) freedom of speech, freedom of press and freedom of association; 3) general direct secret voting; 4) inviolability of citizens and Duma members - bourgeois prejudices... the red mask of a revolutionary has fallen down from the face of a Bolshevik and revealed his real nature of a Black-Hundreder" (Bukeikhan, 1995: 414). Once again, A. Bukeikhanov's words became prophetic: all further policies implemented by the Soviet regime in the national republic confirmed that Bukeikhanov was right.

Taking into account the political situation and the right of the peoples to self-determination declared by the Chairman of the Council of People's Commissars of RSFSR, V.I. Lenin, representatives of Kazakh national intelligentsia started to turn the idea of national independence into action at the II All-Kazakh Congress. The decision about the creation of territorial national autonomy of Kazakh-Kirghiz regions was made, and the autonomy got the name Alash (just as the party). The decision about the autonomy was fraught with acute discussions with representatives of the Ural region, some representatives of the Syr-Darya region and Bukey Horde, who demanded immediate proclamation of an autonomy, and the compromise made by A. Bukeikhanov and his supporters regarding the solution to this issue shows the reasonableness of decisions made by the leaders of Alash Orda, their clear understanding of the situation and realistic estimation of their own abilities.

After the Congress, from December 1917 to April 1918, members of Alash Orda government led by A. Bukeikhanov conducted negotiations with the Chairman of the Council of People's Commissars of RSFSR, V.I. Lenin and the People's Commissar of Nationalities, I.V. Stalin about recognition of the Alash Autonomy. However, Moscow frowned upon the decentralisation processes (apart from Alash, the Turkestan and other autonomies were proclaimed). Having dragged out the negotiations, the Soviet Government started preparation for the declaration of autonomies under the Soviet terms, rejecting to recognise any of the established national autonomies. The ideas of the Bolshevik regime and governments of national autonomies regarding the construction principles of a federation, the competencies of the constituent autonomies and local authorities were different. The Alash leaders were trying to reach an agreement, an "acceptable compromise" with the Soviet Government, but the principle of power organisation "based on democratic grounds with the observation of proportional representation of nationalities" (Amanzholova, 1994: 49) suggested by Alash was absolutely unacceptable for Bolsheviks with their extreme class approach and aiming for dictatorship. The attempts to obtain recognition of the Alash Autonomy from the Council of People's Commissars of RSFSR were unsuccessful. Thus, Alash Orda joined the anti-Soviet bloc. At the same time, Alash Orda reinforced the created autonomy.

We will refrain from providing detailed characteristics of this period, which has been thoroughly described in research literature (Amanzholova, 1994; 2009); the only thing we would like to point out is that this period was marked with the attempts of Alash to find compromise with Soviet Russia and the Bolshevik government, with the wish to consolidate the Kazakh society in the context of a new split, discussions and the fight with UshZhus party that had been created in November 1917. Over this period the activity of the Alash party was fully focused on the operation of Alash Orda government; the issues of party-building gave way to the necessity of finding solutions to the problems of national autonomy and statebuilding.

The fourth, and final, stage in the history of the Alash party (April 1918 - March 1920) - was the period of opposition between the anti-Soviet, anti-Bolshevik activity conducted by the Alash party and Alash Orda government. Refusal of the Alash Orda's suggestions about nationalterritorial autonomy of the regions by the Council of People's Commissars and the People's Commissariat of Nationalities prompted the Alash party to join the anti-Bolshevik union with supporters of the democratic federation and the 
Constituent Assembly. This coalition was viewed by the leaders of the party and autonomy as the opportunity for the people's survival and protection of its vital interests. One of the main reasons to start active anti-Bolshevik struggle was mentioned earlier: Moscow refused to accept the conditions suggested Alash Orda regarding national autonomy of Kazakh regions. Several additional reasons that made the Alash leaders look for allies in the anti-Soviet coalitions were clearly outlined in the memorandum report to the Council of Ministers of the autonomous Siberia sent by the Alash Orda government in July 1918:

Economic breakdown, collapse of commodities, full deterioration of transport, complete destruction of the trade and manufacturing industry in the country, misappropriation of the people's funds in the absence of any law and order added fuel to the flame and caused severe hatred to Bolsheviks in all citizens.... Only due to this, the autonomous regions and peoples liberated as a result of historical events have to embark upon the path of state independence... But all of these regions should not remain isolated: they should seek close contact and unification of forces... Mutual cooperation is necessary for their state-building... (Alash-Orda. Collection of documents, 2002: 125).

Two substages can be identified within this period of the anti-Soviet activity of Alash: April 1918 - March 1919 and March 1919 - March 1920. From April 1918 to March 1919, Alash Orda conducted active organisational activities in the sphere of state-building (three Alash Orda departments were established), creation of people's army (militia), and legislative activities; party unity was maintained. In March 1919, one of the party leaders, A. Baitursynov, defected to the side of the Soviet regime. There was a split in Alash, the organisations and subdivisions of Alash Orda fell apart (in spring 1919, the Turgai subdivision headed by A. Baitursynov fell apart; in December 1919 - the Western subdivision was headed by $Z$. and H. Dosmukhamedov; in
March 1920 - the Eastern, or Semipalatinsk, subdivision was headed by $A$. Bukeikhanov).

The attempts to find allies in the "white" bloc were fruitless: the union with any parties at war with the Soviets (the Siberian government, the Committee of Members of the Constituent Assembly, Dutov, Kolchak, etc.) distanced them from their strategic objectives. None of the allies was going to grant national autonomy to the Kazakhs - all of them remained faithful to the same principle of "united and inseparable Russia". Alash Orda failed to find political allies who could help it stick to a relatively independent national path mainly due to objective reasons beyond its control. In the course of events of 1918-1920, Alash leaders realised the impossibility of implementation of the idea of national sovereignty - mainly due to the political and military situation. In the face of gradual domination seized by the Red Army and assumption of power in the region by the Soviets, the Alash leaders had to accept the conditions dictated to the Alash Orda government by the central authorities, trying to prevent large-scale punitive actions against the Kazakh population that supported the idea of national autonomy. On 9 March, the Kirghiz Military Revolutionary Committee issued an order, according to which the Alash Orda government was abolished. All the laws, instructions and orders it had issued over the period of its existence were declared null and void. Therefore, the Alash party, the Alash Autonomy and its government - Alash Orda People's Council - ceased to exist in March 1920. This was the end of the final fourth period in the Alash history - a period of opposition and antiSoviet activities carried out by the Alash party and Alash Orda government.

\section{Conclusion}

In general, summarising the history of Alash, we agree with the conclusion made by $D$. Amanzholova that the specific feature of development of this movement in 1917-1920 was absence of statics in its organisational forms conditioned mainly by its leaders trying to respond promptly to the quickly changing political situation and also by some deeper 
reasons connected with the state of the Kazakh society. National parties set forth the conditions and ways of modernisation in the most acceptable forms and combinations for each corresponding nation. Thus, studying national parties within the standard Russian system (conservatives, liberal democrats, socialists) is pointless, but drawing parallels between their paths is not only possible but also necessary. Stages of history of national parties existing on the outskirts of the former Russian Empire have the following common characteristics: the first stage - emergence of national political movements; the second stage - the formation of national democratic parties; the third stage the proclamation of national autonomies or attempts to gain autonomy made by national parties; the fourth stage - anti-Bolshevik antiSoviet struggle and abolition of national parties. The history of the Kazakh national party Alash (and the proclaimed Alash Orda Autonomy), as well as the history of the Azerbaijani party Musavat (and the independent Transcaucasian Democratic Federative Republic), the Social Democratic Party of Georgia (and the independent Democratic Republic of Georgia) and other similar national parties (and the national autonomies they established), were similar. Within 3-6 months after abolition of national parties and autonomies, Bolsheviks seized the power and proclaimed Soviet national autonomies with these puppet republics led by the Communist Party.

\section{References}

Akkuly, S.Kh. (2016). Alikhan Bukeikhanov. Almaty: Er Zhonibek.

Amanzholova, D.A. (1993). Party Alash: history and historiography. Kazakhstan: Semipalatinsk.

Amanzholova, D.A. (1994). Kazakh autonomy and Russia. History of the Alash movement. Moscow: Rossiya Molodaya.

Amanzholova, D.A. (2009). On the break. Alash in the ethnopolitical history of Kazakhstan. Almaty: Taimas Publishing House.

Asfendiarov, S.D. (1993). History of Kazakhstan (from ancient times). 2nd edition. Almaty: Kazakh University.
Bochagov, A.K. (1927). Alash-Orda. A brief historical essay on the national-bourgeois movement in Kazakhstan from 1917 to 1919. Kzyl-Orda: State Publishing House of the KSSR.

Brainin, S., \& Shafiro, S. (1933). On the origins of the Alash movement. Bolshevik Kazakhstana, $6,42-48$.

Brainin, S., \& Shafiro, S. (1935). Essays on the history of the Alash-Orda. Kazakhstan: Almaty, 145.

Bukeikhan, A. (1995). Alikhan Bukeikhan. Selection. Almaty: Kazakh encyclopedias.

Grigoryev, V.K. (1989). Confrontation. The Bolsheviks and non-proletarian parties in Kazakhstan in 1917-1920. Kazakhstan: Almaty, 248.

History of Kazakhstan (from ancient times to our days). (2009). In five volumes. Vol. 4. Almaty: Atamura.

Kenzhin, A. (1922). To the historical evaluation of the Alash-Orda activity. Stepnaya Pravda, 247, 14 November.

Koigeldiev, M.K. (1995). Alash kozgalysy. Almaty: Sanat.

Martynenko, N. (1992). Alash-Orda. Collection of documents. Almaty: Aykap.

Mazhitova, Zh.S., Saktaganova, Z., Ilyasov, S., Abdrakhmanova, K., Uskembayev, K., Zuyeva, L., Tleugabilova, K., \& Ogoltseva, E. (2016). Ideological and theoretical foundations of biys' institute in the pre-Soviet historiography. Man In India, 96(10), 3647-3659.

Nurmagambetova, R.K. (2003). Movement "Alash" and "Alash-Orda". Historiography of the problem. 1920's-1990's of the 20th century. Kazakhstan: Almaty, 153.

Nurpesov, K.N. (1995). Alash ham Alashorda. Kazakhstan: Almaty, 255.

Proceedings of the Society for the Study of the Kyrgyz Krai. (1922). Vol. 3. Orenburg, 20-25.

Ryskulov, T. (1984). On the counterrevolutionary Alash-Orda and its fragments. Selected Works. Kazakhstan: Almaty, 206-213. 
Ryskulov, T. (1997). Ryskulov T. Collection of works in 3 volumes. Kazakhstan: Almaty, vol. 2, 199-274.

Ryskulov, T. (1998). Response to the letter of a group of young people in the newspaper "Sovetskaya Steppe" "On the aul, the intelligentsia, the Communist Party and culture". Collected works in three volumes.

Kazakhstan: Almaty, vol. 3, 266-272.

Sarmurzin, A.G. (1990). The Alash-Orda Crash.

On the Past for the Future (Some Actual

Problems of the History of the Communist Party of Kazakhstan in the Light of Glasnost).

Kazakhstan: Almaty, 5-64. 